\title{
The Level of Fibrinogen and Gene Polymorphism in Pregnant Women with Placental Insufficiency
}

\author{
*Evgeny A. Reshetnikov, Lyubov S. Orlova, Irina V. Batlutskaya, Natalya A. Rudyh, Mikhail I. Churnosov \\ Belgorod State University, 308015, Belgorod, Pobedy Street, 85, Russia \\ Email: reshetnikov@bsu.edu.ru
}

Received: 16 $^{\text {th }}$ May 2018, Accepted: 04 ${ }^{\text {th }}$ June 2018, Published: 30 $^{\text {th }}$ June 2018

\begin{abstract}
Objectives: To study the association of genetic polymorphisms of coagulation factors with clinical and laboratory indicators in pregnant women with placental insufficiency with fetal growth retardation. Materials and methods: The study group included 250 pregnant women with placental insufficiency with fetal growth retardation (FGR). The control group consisted of 247 women without FGR. The participants were genotyped for four genetic markers of hereditary thrombophilia: fibrinogen $(-455 \mathrm{G} / \mathrm{A} F I)$, prothrombin (20210G/A $F I I)$, factor V Leiden (1691G/A FV), proconvertin (10976G/A FVII). Results: In the group of pregnant women with FGR, having genotypes -455GA FI and -455AA FI, a higher level of fibrinogen $(4.7 \mathrm{~g} / \mathrm{l})$ is observed compared to women with the genotype $-455 \mathrm{GG} F I$ (4.5 g/1, $\mathrm{p}=0.04)$. Conclusion: Thus, the study conducted on the relationship of polymorphic locus $-455 \mathrm{G} / \mathrm{A}$ FI with a higher level of fibrinogen in pregnant women with fetal growth retardation.
\end{abstract}

Keywords: Placental Insufficiency, Fetal Growth Retardation, Single Nucleotide Polymorphism, Pregnancy.

\section{Introduction}

Placental insufficiency is a syndrome caused by morphofunctional changes in the placenta, the progression of which develops a fetal growth retardation syndrome, often combined with hypoxia (Bamfo, Odibo, 2011, Zollner et al., 2011; Unanyan et al., 2015). Placental insufficiency (PI) is one of the most common complications of pregnancy (Serov et al., 2011; Diner et al., 2016). Perinatal mortality in women who underwent placental insufficiency is among the full-term newborns $10.3 \%$, among preterm infants - $49 \%$ (Serov et al., 2011; Diner et al., 2016). In $60 \%$ of cases, placental insufficiency leads to the development of FGR, which ranks third in the structure of the causes of perinatal morbidity (Serov et al., 2011). Placental insufficiency has a multifactorial nature (Makacariya, Bicadze, 2006, Serov et al., 2011; Zollner et al., 2011).

One of the factors leading to the development of placental insufficiency and FGR is hereditary thrombophilia (Zotz et al., 2008; Facco et al., 2009; Nishizawa et al., 2011; Kosar et al., 2011).

But the results of these studies, obtained by different authors, are often contradictory (Camilleri et al, 2004; Infante-Rivard et al., 2005; Dudding et al., 2008; Zotz et al., 2008; Facco et al., 2009; Ivanov et al., 2009; Shanker et al., 2009; Kosar et al., 2011; Nishizawa et al., 2011; Coriu et al., 2014; Livrinova et al., 2015; Reshetnikov et al., 2017).

\section{Materials and Methods Object of Study}

In total 497 unrelated pregnant women in the third trimester of pregnancy were recruited for the study during 2009-2013. All participants signed an informed consent before entering the study. The clinical and laboratory examination of the participants was conducted in the perinatal center of the Saint Joasaph Belgorod Regional Clinical Hospital. The following inclusion criteria were used to check eligibility of the participants: singleton pregnancy, Russian ethnicity. Patients having congenital malformations of internal genitals, uterine fibroids, anomalies of placental location, isosensitization of $\mathrm{Rh}$ factor or $\mathrm{ABO}$, genetic diseases, were excluded from the study.

250 participants were diagnosed with the syndrome of fetal growth retardation of varying severity. The diagnosis of the syndrome was based on clinical data, ultrasound fetometry (TOSHIBA XARIO SSA-660A) and parameters of growth and weight after the birth. Based on the differences between the fetometric data and nomograms, three degrees of FGR were classified: $1^{\text {st }}$ degree corresponded to the reduction of the estimated gestational ages from the standard ones by 2 weeks, $2^{\text {nd }}$ degree - by 3-4 weeks, and $3^{\text {rd }}$ degree - by more than 4 weeks.

The controls were 247 females without the syndrome of intrauterine growth retardation.

The laboratory study included a clinical blood test (with determination of the number of basic blood elements, hematocrit indicator); biochemical blood test (total protein, total bilirubin, urea, creatinine, level of hepatic aminotransferases, alkaline phosphatase, glucose); coagulogram (prothrombin index, activated partial thromboplastin time, thrombin time (TB), fibrinogen, international normalized ratio (INR), ethanol test, b-naphtholol test), extended study of 


\section{Helix Vol. 8(4): 3491 - 3494}

hemostatic system (detection of soluble fibrin monomer complexes), antithrombin-III, protein $\mathrm{C}$ and protein $\mathrm{S}$, platelet aggregation tests); determination of blood type and $\mathrm{Rh}$ factor. Also, analyzes were performed to exclude the antiphospholipid syndrome (lupus anticoagulant, cardiolipin antibodies, antiphospholipid antibodies) and associated hereditary thrombophilia.

\section{Molecular and Genetic methods}

The participants were genotyped for four genetic markers of hereditary thrombophilia: fibrinogen (455G/A FI), prothrombin (20210G/A FII), factor V Leiden (1691G/A FV), proconvertin (10976G/A FVII).

The material for the study was venous blood, obtained in a volume of 8-9 $\mathrm{ml}$ from the ulnar vein of pregnant women. All polymorphic variants of hereditary thrombophilia were analyzed using the method of polymerase chain reaction (PCR) of DNA synthesis in real-time (real-time-PCR).

\section{Statistical Methods}

The obtained genotypes were checked for their correspondence to the Hardy-Weinberg distribution (HWE) using the $\chi^{2}$-test. Association of the polymorphisms with FGR was estimated by analyzing $2 \times 2$ contingency tables with the $\chi^{2}$-test and the Yates' correction for continuity. The risk was estimated using odds ratio with $95 \%$ confidence intervals $(95 \% \mathrm{CI})$. The median (Me) and interquartile range (Q25-Q75) were used to describe the traits studied, and the MannWhitney test for comparative analysis. The analyses were performed using STATISTICA 6.0 (StatSoft, USA). The Bonferroni correction was applied to adjust for multiple comparisons.

\section{Results}

Characteristics of pregnant women with FGR and control group are shown in Table 1 .

The analysis of clinical and laboratory parameters in pregnant women with FGR and control group was carried out: a general blood test, a biochemical blood test, a coagulogram, as well as the level of antithrombin III and soluble fibrin-monomer complexes (SFMC), a general urine test. The associations of genetic variants of coagulation factors with clinico-laboratory indicators in pregnant women with FGR and in the control group were studied.
Table 1 Physical Characteristics and Various Medical Pathologies in the Study Participants

\begin{tabular}{|c|c|c|c|}
\hline & $\begin{array}{l}\text { FRG } \\
\text { patients, } \\
n(\%)\end{array}$ & $\begin{array}{l}\text { Controls, } \\
\mathrm{n}(\%)\end{array}$ & $\mathrm{p}$ \\
\hline $\mathrm{N}$ & 250 & 247 & \\
\hline $\begin{array}{l}\text { Age, y } \\
\text { (min-max) }\end{array}$ & $\begin{array}{l}26.78 \pm 4.81 \\
(16.0-45.0)\end{array}$ & $\begin{array}{l}26.20 \quad \pm \\
5.01 \\
(19.0- \\
41.0)\end{array}$ & $>0.05$ \\
\hline BMI, $\mathrm{kg} / \mathrm{m}^{2}$ & $23.37 \pm 4.31$ & $\begin{array}{ll}23.90 & \pm \\
3.96 & \end{array}$ & $>0.05$ \\
\hline \multicolumn{4}{|l|}{ Somatic Pathologies } \\
\hline $\begin{array}{l}\text { Essential } \\
\text { Hypertension }\end{array}$ & $50(20.00)$ & $29(11.74)$ & 0.02 \\
\hline $\begin{array}{l}\text { Chronic } \\
\text { Pyelonephritis }\end{array}$ & $63(25.20)$ & $55(22.27)$ & 0.51 \\
\hline Obesity & $23(9.20)$ & $22(8.91)$ & 1.00 \\
\hline Varicose Veins & $13(5.20)$ & $10(4.05)$ & 0.69 \\
\hline $\begin{array}{l}\text { Venous } \\
\text { Thromboembolism } \\
\text { at Pregnancy }\end{array}$ & $4(1.60)$ & $1(0.41)$ & 0.38 \\
\hline $\begin{array}{l}\text { Chronic } \\
\text { Gastroduodenitis }\end{array}$ & $26(10.40)$ & $22(8.89)$ & 0.68 \\
\hline $\begin{array}{l}\text { Cerebrovascular } \\
\text { Disease in History }\end{array}$ & $2(0.80)$ & $0(0.0)$ & 0.50 \\
\hline \multicolumn{4}{|c|}{ Gynecological Pathologies } \\
\hline $\begin{array}{l}\text { Medical Abortion } \\
\text { in History }\end{array}$ & $80(32.00)$ & $65(26.32)$ & 0.20 \\
\hline $\begin{array}{l}\text { Infertility in } \\
\text { History }\end{array}$ & $5(2.00)$ & $8(3.24)$ & 0.56 \\
\hline $\begin{array}{ll}\text { Miscarriage in } \\
\text { History (Total) }\end{array}$ & $46(18.40)$ & $25(10.12)$ & 0.01 \\
\hline $\begin{array}{l}\text { Miscarriage in } \\
\text { First Trimester }\end{array}$ & $36(14.40)$ & $20(8.10)$ & 0.04 \\
\hline $\begin{array}{l}\text { Pregnancy Loss in } \\
\text { First Trimester }\end{array}$ & $12(4.80)$ & $12(4.86)$ & 1.00 \\
\hline Ectopic Pregnancy & $10(4.00)$ & $15(6.07)$ & 0.39 \\
\hline $\begin{array}{l}\text { Disorders of the } \\
\text { Menstrual Cycle in } \\
\text { History }\end{array}$ & $20(8.00)$ & $14(5.67)$ & 0.39 \\
\hline $\begin{array}{l}\text { Pelvic } \\
\text { Inflammatory } \\
\text { Disease in History }\end{array}$ & $58(23.20)$ & $59(23.89)$ & 0.94 \\
\hline $\begin{array}{l}\text { Intrauterine } \\
\text { Infection During } \\
\text { Pregnancy }\end{array}$ & $83(33.20)$ & $80(32.39)$ & 0.68 \\
\hline Preeclampsia & $55(22.00)$ & $68(27.53)$ & 0.19 \\
\hline $\begin{array}{l}\text { Antenatal } \\
\text { Intrauterine Fetal } \\
\text { Death }\end{array}$ & $4(1.60)$ & 0 & 0.14 \\
\hline
\end{tabular}


As a result of the analysis, it was found that a statistically significant higher fibrinogen level was observed in the group of pregnant women with FGR having genotypes -455GA FI and -455AA FI (median $-4.7 \mathrm{~g} / \mathrm{l}$, interquartile range $-4.0-5.5 \mathrm{~g} / \mathrm{l}$ ) compared to with women with genotype -455GG FI (median 4.5 $\mathrm{g} / \mathrm{l}$, interquartile range 4.0-5.1 g/l, $\mathrm{p}=0.04$ ).

Other molecular genetic markers showed no significant associations with clinical and laboratory indicators in pregnant women.

\section{Discussion}

Our study showed that the genetic variants -455GA FI and -455AA FI are associated with an increased level of fibrinogen in pregnant women with fetal growth retardation.

Fibrinogen is a plasma globulin consisting of three pairs of identical polypeptide chains: $\mathrm{A} \alpha-\mathrm{B} \beta-$ and $\gamma$. The sequences of the polypeptide chains of fibrinogen are encoded in three different genes located in the long arm of the chromosome 14.

Several variants of gene polymorphism have been found, which are in total responsible for fluctuations in the level of fibrinogen in the range of $34-50 \%$ (Endler et al., 2003). The -455G/A polymorphism is associated with an increase in the level of fibrinogen (Makacariya, Bicadze, 2006). A high level of fibrinogen in the blood can indicate a high risk of thrombosis (Dyatlova et al., 2015; Makacariya, Bicadze, 2006). Hyperfibrinogenemia is observed in hypercoagulation and in the first stage of DICsyndrome (Dyatlova et al., 2015).

Previously, researchers also established a relationship of polymorphism $-455 \mathrm{G} / \mathrm{A} F I$ with a higher plasma fibrinogen level (Humphries et al., 1987; Makacariya, Bicadze, 2006; Yenicesu et al., 2010). On the contrary, in other works opposite results were obtained (Poursadegh Zonouzi et al., 2013).

In our study, were found no significant associations of polymorphic loci 20210G/A FII, 1691G/A FV, $10976 \mathrm{G} / \mathrm{A} F V I I$ with clinico-laboratory parameters in pregnant women with FGR.

In other works, contradictory results were also obtained.

Thus, several studies have shown the connection of polymorphism 10976G/A FVII with the level of proconvertin in plasma. The presence of the heterozygous variant $10976 \mathrm{GA} F V I I$ was associated with a decrease in the concentration of factor VII in the blood by about 25\%, and in the 10976AA FVII homozygote - with a factor concentration decrease of approximately $50 \%$ compared to the carriers of the variant 10976GG FVII (Makacariya et al., 2006, Seremak-Mrozikiewicz et al., 2009).

Some researchers have identified associations of polymorphisms of $1691 \mathrm{G} / \mathrm{A} F V$ and $20210 \mathrm{G} / \mathrm{A} F I I$ with the risk of developing FGR (Martinelli et al., 2001; Dudding, Attia, 2004; Howley et al., 2005); in contrast, (Infante-Rivard et al., 2002).

Thus, the conducted study on the relationship of polymorphic locus $-455 \mathrm{G} / \mathrm{A}$ FI with a higher level of fibrinogen in pregnant women with FGR. The elevated fibrinogen level associated with the carriage of genotypes -455GA FI and -455AA FI can serve as a marker of thrombophilia risk and the development of fetal development retardation syndrome.

The obtained results broaden the concept of the role of hereditary thrombophilia in the development of fetal growth retardation and their use in practical obstetrics.

\section{Conflict of Interest}

The authors declare that they have no conflicts of interest.

\section{References}

[1] Bamfo, J., Odibo, A., 2011. Diagnosis and Management of Fetal Growth Restriction. J Pregnancy, 2011: 640715.

[2] Camilleri, R.S., Peebles, D., Portmann, C., Everington, T., Cohen, H., 2004. -455G/A beta-fibrinogen gene polymorphism, factor $\mathrm{V}$ Leiden, prothrombin G20210A mutation and MTHFR C677T, and placental vascular complications. Blood Coagul Fibrinolysis, 15(2): 139-147.

[3] Coriu ,L., Copaciu, E., Tulbure, D., Talmaci, R., Secara, D., Coriu, D., Cirstoiu,M., 2014. Inherited thrombophilia in pregnant women with intrauterine growth restriction. Maedica (Buchar), 9(4): 351-355.

[4] Diner, N.M., Uzlova, T.V., Kirsanov, M.S., 2016. Chronic placental insufficiency: issues of diagnosis and obstetric tactics, Vestnik Ural'skoj medicinskoj akademicheskoj nauki, 3: 5-13.

[5] Dudding, T.E., Attia, J., 2004. The association between adverse pregnancy outcomes and maternal factor $\mathrm{V}$ Leiden genotype: a meta-analysis. Thromb Haemost, 91: 700-711.

[6] Dudding, T., Heron, J., Thakkinstian, A., Nurk, E., Golding, J., Pembrey, M., Ring ,S.M., Attia, J., Scott, R.J., 2008. Factor V Leiden is associated with pre-eclampsia but not with fetal growthrestriction: a genetic association study and meta-analysis. J Thromb Haemost, 6(11): 1869-1875.

[7] Dyatlova, L.I., CHesnokova, N. P., Ponukalina, E. V., Rogozhina, I. E., Gluhova, T. N., 2015. Patterns of changes in coagulation potential of blood in preterm 
pregnancy complicated by premature rupture of membranes. Lechashchij vrach, 5: 50

[8] Endler, G., Mannhalter ,C., 2003. Polymorphisms in coagulation factor genes and their impact on arterial and venous thrombosis. Clin Chim Acta, 330(1-2): 3155.

[9] Facco, F., You, W., Grobman, W., 2009. Genetic thrombophilias and intrauterine growth restriction: a meta-analysis. Obstet Gynecol, 113(6): 1206-1216.

[10] Howley, H., Walker, M., Rodger, M.A., 2005. A systematic review of the association between factor $\mathrm{V}$ leiden or prothrombin gene variant and intrauterine growth restriction. Am J Obstet Gynecol, 192: 694-708.

[11] Humphries, S.E., Cook, M., Dubowitz ,M., Stirring, Y., Meade ,T.W., 1987. Role of genetic variation at the fibrinogen locus in determination of plasma fibrinogen concentrations. Lancet, 1(8548): 1452-1455.

[12] Infante-Rivard, C., Rivard ,G.E., Yotov, W.V., Genin, E., Guiguet, M., Weinberg, C., Gauthier, R., Feoli-Fonseca, J.C., 2002. Absence of association of thrombophilia polymorphisms with intrauterine growth restriction. N Engl J Med, 347: 19-25.

[13] Infante-Rivard, C., Rivard, G.E., Guiguet, M., Gauthier, R., 2005. Thrombophilic polymorphisms and intrauterine growth restriction. Epidemiology, 16(3): 281-287.

[14] Ivanov, P., Komsa-Penkova ,R., Konova,E., Kovacheva, K., Ivanov, I., Ivanov, M., Tanchev,S., 2009. Inherited thrombophilic factors in women with unexplained intrauterine fetal deaths. Akush Ginekol (Sofiia), 48(4): 3-7.

[15] Kosar, A., Kasapoglu, B., Kalyoncu, S., Turan ,H., Balcik ,O.S., Gümüs ,E.I., 2011. Treatment of adverse perinatal outcome in inherited thrombophilias: a clinical study. Blood Coagul Fibrinolysis, 22(1): 14-18.

[16] Livrinova, V., Lega, M.H., Dimcheva, A.H., Samardziski I., Isjanovska, R., 2015. Factor $\mathrm{V}$ Leiden, prothrombin and MTHFR mutation in patients with preeclamsia, intrauterine growth restriction and placental abruption. Open Access Maced J Med Sci, 3(4): 590-594.

[17] Makacariya, A.D., Bicadze, V.O., 2006. Antiphospholipid syndrome, genetic thrombophilia in the pathogenesis of the main forms of obstetric pathology. Russkij medicinskij zhurnal, special issue: 2-10.

[18] Martinelli,P., Grandone, E., Colaizzo, D., Paladini, D., Scianname, N., Margaglione
M., Di Minno, G., 2001. Familial thrombophilia and the occurrence of fetal growth restriction. Haematologica, 86: 428431.

[19] Nishizawa, H., Ota, S., Suzuki, M., Kato, T., Sekiya ,T., Kurahashi ,H., Udagawa, Y., 2011. Comparative gene expression profiling of placentas from patients with severe preeclampsia and unexplained fetal growth restriction. Reprod Biol Endocrinol, 9: 107119.

[20] Poursadegh Zonouzi, A., Chaparzadeh ,N., Ghorbian ,S., Sadaghiani, M.M., Farzadi ,L., Ghasemzadeh ,A., Kafshdooz, T., Sakhinia, M., Sakhinia, E., 2013. The association between thrombophilic gene mutations and recurrent pregnancy loss. J Assist Reprod Genet, 30(10): 1353-1359.

[21] Reshetnikov, E., Zarudskaya, O., Polonikov, A., Bushueva, O., Orlova, V., Krikun, E., Dvornyk, V., Churnosov, M., 2017. Genetic markers for inherited thrombophilia are associated with fetal growth retardation in the population of Central Russia. J Obstet Gynaecol Res, 43(7): 1139-1144.

[22] Seremak-Mrozikiewicz, A., Drews, K., Kurzawińska ,G., Barlik, M., Mrozikiewicz, P.M., 2009. The connection between Arg353Gln polymorphism of coagulation factor VII and recurrent miscarriages. Ginekol Po.l, 80(1): 8-13.

[23] Serov, V.N., 2011. Prevention of maternal mortality. Obstetrics and Gynecology, 7(1): 4-10.

[24] Unanyan, A.L., Arakelov, S.EH., Polonskaya, L.S., Guriev, T.D., Il'icheva, T.S., Baburin ,D.V., Kossovich ,Y.U.M., 2015. Placental insufficiency: peculiarities of etiopathogenesis, therapy and prophylaxis. Consilium Medicum, 17(6): 37-40.

[25] Yenicesu, I., Cetin, M., Ozdemir, O., Cetin ,A., Ozen, F., Yenicesu ,C., Yildiz, C, Kocak, N., 2010. A prospective case-control study analyzes 12 thrombophilic gene mutations in Turkish couples with recurrent pregnancy loss. Am J Reprod Immunol, 63: 126-136.

[26]Zollner U., Rehn M., Girschick G., Dietl J., 2011. Obstetric management of fetal growth retardation. $\mathrm{Z}$ Geburtshilfe Neonato.l, 215(2): 49-59.

[27]Zotz, R.B., Sucker, C., Gerhardt, A., 2008. Thrombophilia in pregnancy: venous thromboembolism, fetal loss, preeclampsia, intrauterine growth restriction. Hamostaseologie, 28(5): 455-464. 